\title{
Effect of Silicon on Growth and Temperature Stress Tolerance of Nephrolepis exaltata 'Corditas'
}

\author{
Iyyakkannu Sivanesan ${ }^{1}$, Moon Sook Son ${ }^{2}$, Prabhakaran Soundararajan², and Byoung Ryong Jeong ${ }^{1,2,3^{*}}$ \\ ${ }^{1}$ Institute of Agriculture and Life Science, Gyeongsang National University, Jinju 660-701, Korea \\ ${ }^{2}$ Department of Horticulture, Division of Applied Life Science (BK21 Plus), Graduate School, Gyeongsang National University, Jinju 660-701, Korea \\ ${ }^{3}$ Research Institute of Life Science, Gyeongsang National University, Jinju 660-701, Korea
}

\begin{abstract}
Effect of silicon (Si) nutrition on growth and temperature stress tolerance of Nephrolepis exaltata 'Corditas' grown in a soilless substrate was examined. In vitro-grown acclimatized plantlets were transplanted into the pots containing a coir-based substrate. A nutrient solution containing 0,50 , or $100 \mathrm{mg} \cdot \mathrm{L}^{-1} \mathrm{Si}$ was supplied through a drip-irrigation system. After $5 \mathrm{months}$ of cultivation, Si-treated and -untreated plants were grown at 10,25 , or $40 \pm 1^{\circ} \mathrm{C}$ under a $12 \mathrm{~h}$ photoperiod with $530 \mu \mathrm{mol} \cdot \mathrm{m}^{-2} \cdot \mathrm{s}^{-1}$ PPFD and 60\% RH. After 7 days, chlorophyll content and chlorophyll fluorescence parameters were measured. Silicon nutrition had a negative effect on growth characteristics of $N$. exaltata 'Corditas'. However, Si-treated plants had more tolerance to temperature stress than the control plants. The $\mathrm{Fv} / \mathrm{Fm}$ value was not significantly different when the plants were exposed to $25^{\circ} \mathrm{C}$. However, significant difference in Fv/Fm was recorded when plants were exposed to 10 or $40^{\circ} \mathrm{C}$. Thus, Fv/Fm could be used as an indicator of low and high temperature tolerance in ferns. The present study also suggests that application of Si may be used to enhance temperature tolerance of ferns.
\end{abstract}

Additional key words: Boston fern, chlorophyll content, chlorophyll fluorescence, heat stress, plant height

\section{Introduction}

Silicon (Si) is the second most abundant element in the soil and a mineral element for most of the world's plant life. Most $\mathrm{Si}$ is present in the soil as insoluble oxides or silicates, although soluble silicic acid occurs in the range of 0.1-0.6 mM (Epstein, 1994). The availability of Si in the soil is governed not only by $\mathrm{Si}$ polymorphs but also by a number of factors which include soil moisture, temperature, soil $\mathrm{pH}$, organic matter complexes, redox potential, particle size distribution, sesqui-oxide colloids, the presence of aluminium, iron and phosphate ions, as well as various exchangeable/dissolution reactions (Drees et al., 1989). Silicon has been reported to be beneficial for growth and development of graminaceous plants such as rice, sugarcane and wheat (Liang et al., 2007). However, recent studies have shown that the Si nutrition enhanced growth traits in carnation (Bae et al., 2010), chrysanthemum 'Backwang' (Moon et al., 2008), gerbera (Kamenidou et al., 2010; Savvas et al., 2002), kalanchoe (Bae et al., 2010), sunflower (Kamenidou et al., 2008), rose (Ehret et al., 2005; Hwang et al., 2005), and zinnia (Kamenidou et al., 2009). Furthermore, application of $\mathrm{Si}$ has been shown to be able to control diseases (Rodrigues et al., 2003; Voogt and Sonneveld, 2001) and pests (Jeong et al., 2012; Ranganathan et al., 2006), alleviate toxicity of some heavy metals (Shi et al., 2010), and enhance resistance to drought (Chen et al., 2011), salinity (MateosNaranjo et al., 2013), and temperature stresses (Epstein, 1999; Ma and Yamaji, 2006).

Ferns have been cultivated for their ornamental foliage and their demand as indoor plants has been increasing. The most frequently used indoor ferns are the Boston ferns

\footnotetext{
*Comesponding author: brjeong@gnu.ac.kr

※ Received 29 May 2013; Revised 7 August 2013; Accepted 13 August 2013. This research was supported by Technology Development Program for Agriculture and Forestry, Ministry for Food, Agriculture, Forestry and Fisheries, Republic of Korea, Project No 108102-5. Moon Sook Son and Prabhakaran Soundararajan were supported by a scholarship from the BK21 Plus Program, the Ministry of Education, Science and Technology, Korea. 
(Nephrolepis exaltata and cultivars), which come in a variety of textures. Nephrolepis exaltata 'Corditas' is a fast and uniform grower belonging to the family Nephrolepidaceae. Its modest size and maximum frond length of $30 \mathrm{~cm}$ make this dwarf fern ideal for smaller pot sizes and arrangements. Plants frequently encounter adverse growth conditions (Krasensky and Jonak, 2012). Temperature is one of the primary abiotic factors which influence the growth and development of many plant species. Ferns vary greatly in their temperature requirements. Most grow best at daytime temperatures of 18 to $27^{\circ} \mathrm{C}$ and the nighttime temperature is about $5^{\circ} \mathrm{C}$ cooler than the daytime temperature (Hoshizaki and Moran, 2001). Boston ferns exposed to temperatures below $15.5^{\circ} \mathrm{C}$ and above $35^{\circ} \mathrm{C}$ may display stunted growth and yellow fronds (Dawson et al., 1991; Erwin et al., 1993). The optimal supply of Si increases the plant tolerance to many abiotic stresses including low and high temperature (Ma and Yamaji, 2006). Scientists have observed silica bodies in fern tissues (Hodson et al., 2005; Piperno, 1988), but no reports are yet available concerning the effect of Si on growth of ferns. In this study, we investigated the effect of Si on growth and temperature stress tolerance in $N$. exaltata 'Corditas'.

\section{Materials and Methods}

In vitro-grown plantlets were acclimatized in the greenhouse. After a month, uniform plantlets were transplanted into $10 \mathrm{~cm}(370 \mathrm{~mL})$ plastic pots containing a coir-based substrate (Tosilee medium, Shinan Grow Co., Korea). A nutrient solution containing 0,50 , or $100 \mathrm{mg} \cdot \mathrm{L}^{-1} \mathrm{Si}$ was supplied through a drip-irrigation system. Silicon was added to the nutrient solution in the form of potassium silicate $\left(\mathrm{K}_{2} \mathrm{SiO}_{3}\right)$, and additional $\mathrm{K}$ introduced by $\mathrm{K}_{2} \mathrm{SiO}_{3}$ was subtracted from $\mathrm{KNO}_{3}$ and the resulted nitrate loss was supplemented with nitric acid. The composition of nutrient solution was $\left(\mathrm{mg} \cdot \mathrm{L}^{-1}\right): 354 \mathrm{Ca}\left(\mathrm{NO}_{3}\right)_{2} \cdot 4 \mathrm{H}_{2} \mathrm{O}, 123 \mathrm{MgSO}_{4} \cdot 7 \mathrm{H}_{2} \mathrm{O}, 252.5$ $\mathrm{KNO}_{3}, 115 \mathrm{NH}_{4} \mathrm{H}_{2} \mathrm{PO}_{4}, 0.62 \mathrm{H}_{3} \mathrm{BO}_{3}, 0.062 \mathrm{CuSO}_{4} \cdot 5 \mathrm{H}_{2} \mathrm{O}, 2$ Fe-EDTA, $1.1 \mathrm{MnSO}_{4} \cdot 4 \mathrm{H}_{2} \mathrm{O}, 0.04 \mathrm{H}_{2} \mathrm{MoO}_{4}$, and $0.575 \mathrm{ZnSO}_{4}$. $7 \mathrm{H}_{2} \mathrm{O}$. All treatment solutions were adjusted to $\mathrm{pH} 5.8$ with nitric acid or potassium hydroxide at the beginning of the experiment and replacement. Each treatment consisted of three replicates and each replicate contained 45 plants. The plants were randomly arranged among nine beds in the greenhouse and were grown under a normal day-light condition with night/day set temperatures of $19 / 27^{\circ} \mathrm{C}$ and $60-70 \%$ relative humidity (RH). Plant height, width, number of fronds, root length, and fresh and dry weights of frond and root were recorded after 5 months of cultivation. Dry weight was measured after $72 \mathrm{~h}$ of drying at $70^{\circ} \mathrm{C}$ in a forced air dry oven.

After five months of cultivation, Si-treated and the -untreated plants were placed in an environment controlled chamber. A nutrient solution containing 0,50 , or $100 \mathrm{mg} \cdot \mathrm{L}^{-1}$ $\mathrm{Si}$ was supplied uniformly twice a day. Plants were maintained at 10,25 , or $40 \pm 1^{\circ} \mathrm{C}$ under a $12 \mathrm{~h}$ photoperiod with 530 $\mu \mathrm{mol} \cdot \mathrm{m}^{-2} \cdot \mathrm{s}^{-1}$ photosynthetic photon flux density (PPFD), and $60 \%$ RH. Treatments were started 3 days after incubation at $25^{\circ} \mathrm{C}$. Each treatment consisted of three replicates and each replicate contained 7 plants. After 7 days, chlorophyll (Chl) content and chlorophyll fluorescence parameters were measured. To estimate $\mathrm{Chl}$ content, frond tissue $(0.01 \mathrm{~g})$ was homogenized in $5 \mathrm{~mL}$ of ice-cold $80 \%(\mathrm{v} / \mathrm{v})$ acetone, and then centrifuged at $2500 \mathrm{~g}$ for $15 \mathrm{~min}$. The supernatant was decanted and the absorbance was measured at 645 and $663 \mathrm{~nm}$. Chlorophyll concentration was determined according to the procedure developed by Arnon (1949). Chlorophyll fluorescence parameters were measured using a chlorophyll fluorometer (PAM- 2100, Walz, Germany). Fronds were dark adapted for at least 30 min before the chlorophyll fluorescence measurements.

Plants were harvested after 5 months of cultivation for chemical analysis. For each treatment five samples were taken. Dried samples (1.0 g) ground with a stainless mill (Cytclotec, Model 1093, Tector, Hoganas, Sweden) was ashed in a Nabertherm muffle furnace (Model LV 5/11/B180, Lilienthal, Bremen, Germany), for $4 \mathrm{~h}$ at $525^{\circ} \mathrm{C}$. The ash was dissolved in $5 \mathrm{~mL} 25 \% \mathrm{HCl}$, followed by $20 \mathrm{~mL}$ of hot distilled water $\left(\mathrm{DH}_{2} \mathrm{O}\right)$ and brought to $100 \mathrm{~mL}$ with deionized water. Calcium (Ca), potassium $(\mathrm{K})$, magnesium $(\mathrm{Mg})$, phosphorus $(\mathrm{P})$, sulfur $(\mathrm{S})$, boron $(\mathrm{B})$, copper $(\mathrm{Cu})$, iron $(\mathrm{Fe})$, manganese $(\mathrm{Mn})$, and zinc $(\mathrm{Zn})$ concentrations in digested frond and root samples were measured by using an inductively coupled plasma (ICP) spectrometer (Optima 4300DV/5300DV, Perkin Elmer, Germany).

Extraction of $\mathrm{Si}$ in the frond and root samples was conducted by a slight modification of the autoclave-induced digestion method (Elliott and Snyder, 1991). Dry, ground samples $(0.1 \mathrm{~g})$ were placed in $50 \mathrm{~mL}$ polyethylene tubes and wetted with $3 \mathrm{~mL}$ of a $30 \%$ hydrogen peroxide solution. Then five drops of octyl alcohol were added to prevent excessive foaming. To each tube $4.5 \mathrm{~g}$ of $\mathrm{NaOH}$ was added, followed by $6.0 \mathrm{~mL}$ of $\mathrm{DH}_{2} \mathrm{O}$ and each tube was gently vortexed and covered with a loose fitting plastic cap. The tubes were placed in an autoclave at $138 \mathrm{kPa}$ for $1 \mathrm{~h}$. After atmospheric pressure was reached, tubes were removed and the contents were brought to $50 \mathrm{~mL}$ with $\mathrm{DH}_{2} \mathrm{O}$. The digested sample Si concentration was determined color- 
imetrically according to Sivanesan et al. (2010).

Statistical analyses of the data were carried out using SAS (Statistical Analysis System, V. 9.1, Cary, NC, USA) program. All data were subjected to analysis of variance (ANOVA) and Duncan's multiple range tests was used to test significant difference between means.

\section{Results and Discussion}

Silicon nutrition either increased or decreased plant height in several plant species such as bracteantha, carnation, fuchsia, kalanchoe, lobelia, rice, and tomato (Bae et al., 2010; Kim et al., 2002; Mattson and Leatherwood, 2010; Sivanesan et al., 2011). In the present study, plant height was suppressed by 2.7 and $8.1 \%$ when the nutrient solution was supplemented with 50 and $100 \mathrm{mg} \cdot \mathrm{L}^{-1} \mathrm{Si}$, respectively, compared with the control. Similar result was also reported in ornamental sunflower (Kamenidou et al., 2008), Tagetes patula 'Boy Orange' and 'Yellow Boy' (Sivanesan et al., 2010) and zinnia (Kamenidou et al., 2009). Plant width was also reduced by 6.9 and $13.8 \%$ when the plants were treated with 50 and $100 \mathrm{mg} \cdot \mathrm{L}^{-1} \mathrm{Si}$, respectively, compared with the control (Table 1). The mean number of fronds decreased with increasing concentrations of $\mathrm{Si}$ in the nutrient solution. Compared with the control, addition of 50 and $100 \mathrm{mg} \cdot \mathrm{L}^{-1}$ Si significantly reduced the mean number of fronds by 31.8 and $42.3 \%$, respectively. Root length was not affected by $50 \mathrm{mg} \cdot \mathrm{L}^{-1} \mathrm{Si}$ treatment while, the longest root length was measured in $100 \mathrm{mg} \cdot \mathrm{L}^{-1} \mathrm{Si}$ treatment. However, Si treatment significantly reduced fresh and dry weights of roots as compared with the control (Table 1). Similarly, fresh and dry weights of fronds decreased with increasing concentrations of $\mathrm{Si}$ in the nutrient solution. When the nutrient solution was supplemented with 100 $\mathrm{mg} \cdot \mathrm{L}^{-1} \mathrm{Si}$, fresh and dry weights of fronds were reduced by 9.1 and $10.3 \%$, respectively, compared with the control.

In the present study, Si nutrition had a negative effect on the growth characteristics of $N$. exaltata 'Corditas' by decreasing the concentrations of tissue nutrients content.
However, many reports have shown that Si plays an important role in protecting plant from abiotic stresses (Liang et al., 2007; Ma, 2004; Ma and Yamaji, 2006). Temperature stress is one of the main abiotic stresses that limit plant growth and survival. The morphological symptoms of heat stress include scorching of leaves and twigs, leaf senescence and abscission, shoot and root growth inhibition (Wahid et al., 2007). In the present study, frond scorch was observed when plants were treated with extreme temperature. Severe scorch occurred in the Si-deprived plants when they were exposed to $40^{\circ} \mathrm{C}$ (Fig. 1). Heat stress may cause severe water loss when transpiration exceeds moisture absorption by roots. A portion or all of the leaf can be killed with long-term exposure to unfavorable temperatures. Studies indicate that $\mathrm{Si}$ is mainly transported passively in the transpiration stream, and is accumulated at sites of high transpiration (Wiese et al., 2007). Silicon application decreased transpiration rate in maize (Gao et al., 2006), and rice

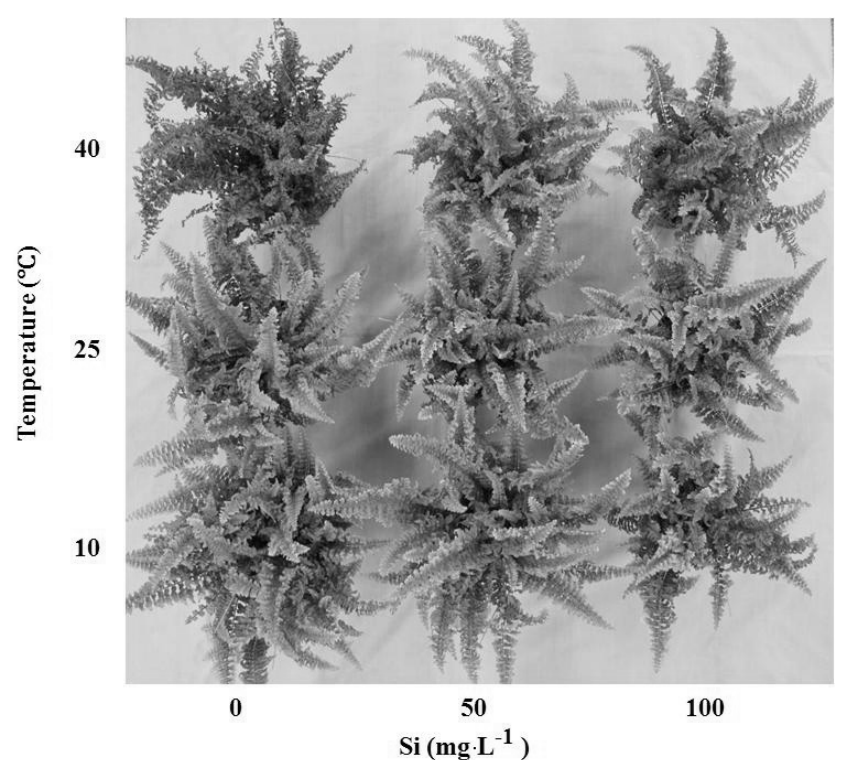

Fig. 1. Effect of silicon on tolerance to temperature stress in Nephrolepis exaltata 'Corditas'.

Table 1. Effect of silicon on the growth of Nephrolepis exaltata 'Corditas' at 5 months after treatment.

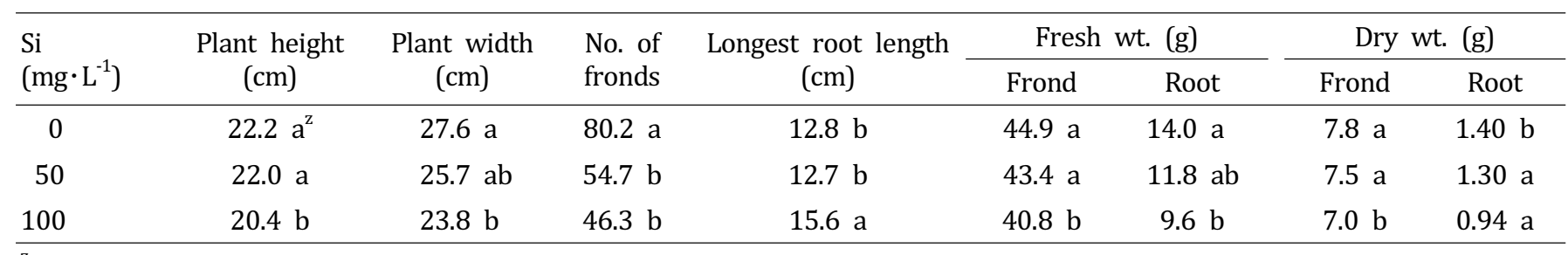

${ }^{\mathrm{z}}$ Mean separation within columns by Duncan's multiple range test, $P \leq 0.05$. 
(Ma, 2004). In the present study, $100 \mathrm{mg} \cdot \mathrm{L}^{-1} \mathrm{Si}$ treatment significantly increased the Si concentration of frond. The result suggest that high amount of $\mathrm{Si}$ deposition may reduce the transpiration rate and thereby enhance high temperature tolerance in $N$. exaltata 'Corditas'. The temperature treatment had a significant effect on $\mathrm{Chl} \mathrm{a,} \mathrm{Chl} \mathrm{b,} \mathrm{and} \mathrm{total} \mathrm{Chl} \mathrm{content}$ of $N$. exaltata 'Corditas'. The content of $\mathrm{Chl}$ a or $\mathrm{Chl} \mathrm{b}$ reduced significantly when the Si-deprived plants were treated with 10 and $40^{\circ} \mathrm{C}$, respectively. When the Si-treated plants $\left(100 \mathrm{mg} \cdot \mathrm{L}^{-1}\right)$ were exposed to 10,25 or $40^{\circ} \mathrm{C}$, the total Chl content was increased by 52.7, 20.5 and 79.6\%, respectively, compared with the control. Similar results were also observed in bermudagrass (Brecht et al., 2009). Silicon also increases the tolerance to heat stress in rice (Ma, 2004). Agarie et al. (1998) reported electrolyte leakage

Table 2. Effect of temperature and silicon concentration on chlorophyll a, b, total chlorophyll, and chlorophyll fluorescence (Fv/Fm) ratio of Nephrolepis exaltata 'Corditas'.

\begin{tabular}{|c|c|c|c|c|c|}
\hline \multirow{2}{*}{$\begin{array}{l}\text { Temp. } \\
\left({ }^{\circ} \mathrm{C}\right)\end{array}$} & \multirow{2}{*}{$\begin{array}{c}\mathrm{Si} \\
\left(\mathrm{mg} \cdot \mathrm{L}^{-1}\right)\end{array}$} & \multicolumn{3}{|c|}{ Concentration $\left(\mu \mathrm{g} \cdot \mathrm{mg}^{-1}\right.$ fresh wt.) } & \multirow{2}{*}{$\mathrm{Fv} / \mathrm{Fm}$} \\
\hline & & Chl a & Chl b & Total Chl & \\
\hline \multirow[t]{3}{*}{10} & 0 & $1.23 \mathrm{~b}^{\mathrm{y}}$ & $0.39 \mathrm{~b}$ & $1.61 \mathrm{c}$ & $0.52 \mathrm{~b}$ \\
\hline & 50 & $1.36 \mathrm{~b}$ & $0.55 \mathrm{a}$ & $1.91 \mathrm{~b}$ & $0.66 \mathrm{a}$ \\
\hline & 100 & $1.83 \mathrm{a}$ & $0.63 \mathrm{a}$ & $2.46 \mathrm{a}$ & $0.70 \mathrm{a}$ \\
\hline \multirow[t]{3}{*}{25} & 0 & $1.90 \mathrm{~b}$ & $0.63 \mathrm{~b}$ & $2.54 \mathrm{c}$ & $0.78 \mathrm{a}$ \\
\hline & 50 & $2.01 \mathrm{a}$ & $0.79 \mathrm{a}$ & $2.79 \mathrm{~b}$ & $0.80 \mathrm{a}$ \\
\hline & 100 & $2.17 \mathrm{a}$ & $0.91 \mathrm{a}$ & $3.06 \mathrm{a}$ & $0.80 \mathrm{a}$ \\
\hline \multirow[t]{3}{*}{40} & 0 & $1.09 \mathrm{c}$ & $0.44 \mathrm{c}$ & $1.52 \mathrm{c}$ & $0.28 \mathrm{c}$ \\
\hline & 50 & $1.44 \mathrm{~b}$ & $0.55 \mathrm{~b}$ & $2.00 \mathrm{~b}$ & $0.50 \mathrm{~b}$ \\
\hline & 100 & $1.93 \mathrm{a}$ & $0.80 \mathrm{a}$ & $2.73 \mathrm{a}$ & $0.59 \mathrm{a}$ \\
\hline
\end{tabular}

${ }^{\mathrm{z}}$ Values were obtained at 7 days after treatment.

${ }^{\mathrm{y}}$ Mean separation within columns in each temperature by Duncan's multiple range test, $P \leq 0.05$. caused by high temperature was less pronounced in leaves grown with $\mathrm{Si}$ than in those grown without $\mathrm{Si}$. These results suggest that Si may be involved in the thermal stability of lipids in cell membranes although the mechanism has not been elucidated (Ma, 2004). Chlorophyll fluorescence has been widely used as an early indication of many kinds of plant stress, including temperature (Chen et al., 2012; Kalaji et al., 2011; Maxwell and Johnson, 2000). Chlorophyll fluorescence parameter Fv/Fm was more sensitive to temperature in plants (Salvucci and Crafts-Brander, 2004). In the present study, Fv/Fm value was not significantly different when the plants were exposed to $25^{\circ} \mathrm{C}$. However, significant difference in $\mathrm{Fv} / \mathrm{Fm}$ was recorded when plants were exposed to 10 and $40^{\circ} \mathrm{C}$. Thus, $\mathrm{Fv} / \mathrm{Fm}$ could be used as an indicator of low and high temperature tolerance (Guo et al., 2006; Jiang and Howell, 2002). When Si-treated plants $\left(100 \mathrm{mg} \cdot \mathrm{L}^{-1}\right)$ were exposed to 10 or $40^{\circ} \mathrm{C}, \mathrm{Fv} / \mathrm{Fm}$ value was increased by 34.6 and $110.7 \%$, respectively, compared with the control. The results indicate that photosystem II function is not significantly affected by temperature stress, when Si was supplied to N. exaltata 'Corditas'.

The application of Si has been reported to affect the tissue nutrient concentrations of many plant species such as alfalfa (Wang and Han, 2007), bean (Zuccarini, 2008), chrysanthemum (Sivanesan et al., 2013), gerbera (Kamenidou et al., 2010), and rice (Guo et al., 2005). In the present study, $100 \mathrm{mg} \cdot \mathrm{L}^{-1} \mathrm{Si}$ treatment reduced both frond and root tissue concentration of Ca by 14.9 and $14.0 \%$, respectively, compared with the control. Similar result was also observed in sunflower (Kamenidou et al., 2008) and rice (Ma and Takahashi, 1993). Compared with the control, $50 \mathrm{mg} \cdot \mathrm{L}^{-1}$ Si treatment significantly reduced $(0.97 \%)$ or non-significantly increased (11.7\%) the concentration of $\mathrm{K}$ in frond and root tissue, respectively. In contrast, $100 \mathrm{mg} \cdot \mathrm{L}^{-1} \mathrm{Si}$ treatment increased $(10.9 \%)$ or reduced $(3.6 \%)$ the concentration of $\mathrm{K}$ in frond and root tissue, respectively, compared with

Table 3. Mineral concentration in frond and root of Nephrolepis exaltata as affected by Si application.

\begin{tabular}{|c|c|c|c|c|c|c|c|c|c|c|c|c|}
\hline \multirow{2}{*}{ Organ } & \multirow{2}{*}{$\begin{array}{c}\mathrm{Si} \\
\left(\mathrm{mg} \cdot \mathrm{L}^{-1}\right)\end{array}$} & \multicolumn{5}{|c|}{ Concentration (mg $\cdot \mathrm{g}^{-1}$ dry wt.) } & \multicolumn{6}{|c|}{ Concentration $\left(\mu \mathrm{g} \cdot \mathrm{g}^{-1}\right.$ dry wt.) } \\
\hline & & $\mathrm{Ca}$ & $\mathrm{K}$ & $\mathrm{Mg}$ & $\mathrm{P}$ & $S$ & B & $\mathrm{Cu}$ & $\mathrm{Fe}$ & $\mathrm{Mn}$ & $\mathrm{Zn}$ & $\mathrm{Si}$ \\
\hline \multirow[t]{3}{*}{ Frond } & 0 & $11.03 \mathrm{a}^{\mathrm{z}}$ & $31.78 \mathrm{~b}$ & $42 \mathrm{a}$ & $5.70 \mathrm{a}$ & $3.17 \mathrm{~b}$ & $1.85 \mathrm{~b}$ & $10.18 \mathrm{a}$ & 09.50 d & $26.66 \mathrm{a}$ & $42.55 \mathrm{a}$ & $163 \mathrm{c}$ \\
\hline & 50 & $11.02 \mathrm{a}$ & $31.47 \mathrm{~b}$ & $4.16 \mathrm{a}$ & $5.77 \mathrm{a}$ & $3.91 \mathrm{a}$ & $42.28 \mathrm{~b}$ & $9.42 \mathrm{~b}$ & $90.70 \mathrm{a}$ & $24.11 \mathrm{ab}$ & $38.33 \mathrm{ab}$ & $452 \mathrm{~b}$ \\
\hline & 100 & $9.39 \mathrm{~b}$ & $35.23 \mathrm{a}$ & $4.28 \mathrm{a}$ & $5.54 \mathrm{a}$ & $3.18 \mathrm{~b}$ & $46.23 \mathrm{a}$ & $9.03 \mathrm{~b}$ & $69.03 \mathrm{~b}$ & $22.89 \mathrm{~b}$ & $36.68 \mathrm{~b}$ & $600 \mathrm{a}$ \\
\hline \multirow[t]{3}{*}{ Root } & 0 & $9.50 \mathrm{a}$ & $15.47 \mathrm{a}$ & $3.22 \mathrm{a}$ & $3.54 \mathrm{a}$ & $2.40 \mathrm{a}$ & $16.95 \mathrm{a}$ & $32.25 \mathrm{a}$ & $72.70 \mathrm{~b}$ & $33.65 \mathrm{a}$ & $59.03 \mathrm{~b}$ & $214 \mathrm{c}$ \\
\hline & 50 & $8.72 a b$ & $17.19 \mathrm{a}$ & $3.14 \mathrm{a}$ & $3.38 \mathrm{ab}$ & $2.43 \mathrm{a}$ & $13.85 \mathrm{~b}$ & $31.55 \mathrm{a}$ & $86.35 \mathrm{a}$ & $31.18 \mathrm{a}$ & $69.88 \mathrm{a}$ & 647 \\
\hline & 100 & $8.18 \mathrm{~b}$ & $14.92 \mathrm{a}$ & $2.89 \mathrm{~b}$ & $3.21 \mathrm{~b}$ & $2.04 \mathrm{~b}$ & $16.35 \mathrm{a}$ & $27.83 \mathrm{~b}$ & $67.95 \mathrm{c}$ & $28.60 \mathrm{~b}$ & $52.70 \mathrm{c}$ & 960 \\
\hline
\end{tabular}

${ }^{\mathrm{z}}$ Mean separation within columns in each organ by Duncan's multiple range test, $P \leq 0.05$. 
the control. Similarly, addition of Si decreased leaf tissue $\mathrm{K}$ concentration in bean (Zuccarini, 2008) and chrysanthemum (Sivanesan et al., 2013). Liang et al. (1996) reported the K uptake by solution-cultured barley plants increased following Si applications. Compared with the control, 50 or $100 \mathrm{mg} \cdot \mathrm{L}^{-1}$ Si treatment reduced Mg concentration of frond and root tissue by 5.8 and $10.2 \%$, respectively. Similarly, $100 \mathrm{mg} \cdot \mathrm{L}^{-1}$ Si treatment reduced $\mathrm{P}$ concentration of frond and root tissue by 2.8 and $9.3 \%$, respectively. However, $50 \mathrm{mg} \cdot \mathrm{L}^{-1}$ $\mathrm{Si}$ treatment increased frond tissue concentration of $\mathrm{P}$ by $1.2 \%$. The Si treatment tends to increase the P concentration in the green tops of sugarcane (Roy et al., 1971), but decreased in rice (Guo et al., 2005; Ma and Takahashi, 1990). Compared with the control, 50 or $100 \mathrm{mg} \cdot \mathrm{L}^{-1} \mathrm{Si}$ treatment significantly increased $(23.3 \%)$ or reduced $(15.0 \%)$ the concentration of $\mathrm{S}$ in frond and root tissue, respectively.

The Si treatment increased (10.5\%) or reduced (18.2\%) the concentration of B in frond and root tissue, respectively, compared with the control. Both frond and root tissue concentration of $\mathrm{Cu}$ reduced with increasing $\mathrm{Si}$ concentration in the nutrient solution. The Fe concentration of frond and root tissue increased or reduced when plants were treated with 50 and $100 \mathrm{mg} \cdot \mathrm{L}^{-1} \mathrm{Si}$, respectively. Similar results have also been reported in alfalfa (Wang and Han, 2007), chrysanthemum (Sivanesan et al., 2013), and gerbera (Kamenidou et al., 2010). The Mn concentration of frond and root tissue also reduced with increasing $\mathrm{Si}$ concentration in the nutrient solution. Compared with the control, frond tissue concentration of $\mathrm{Zn}$ decreased 9.9 and $13.8 \%$ when plants were treated with 50 and $100 \mathrm{mg} \cdot \mathrm{L}^{-1} \mathrm{Si}$, respectively. Root tissue concentration of $\mathrm{Zn}$ increased (18.4\%) or decreased (6.5\%) when plants were treated with 50 and $100 \mathrm{mg} \cdot \mathrm{L}^{-1}$ $\mathrm{Si}$, respectively, compared with the control. Both frond and root tissue concentrations of Si significantly increased linearly with increasing $\mathrm{Si}$ concentration in the nutrient solution. The $100 \mathrm{mg} \cdot \mathrm{L}^{-1}$ Si treatment increased the Si concentration of frond and root tissue by $268.1 \%$ and $348.6 \%$, respectively, compared with the control.

In conclusion, Si nutrition significantly reduced the mean number of fronds, fresh and dry weights of fronds and roots. Similarly, $\mathrm{Si}$ application decreased significantly tissue concentrations of $\mathrm{Ca}, \mathrm{Mg}, \mathrm{P}, \mathrm{Cu}, \mathrm{Fe}, \mathrm{Mn}$, and $\mathrm{Zn}$. The reduction of biomass may have resulted from changes in the concentrations of inorganic nutrients in leaf or root tissue due to $\mathrm{Si}$ application. The Fv/Fm value decreased during low or high temperature stress suggesting that Fv/Fm could be used as an indicator of low and high temperature tolerance in ferns. The present study also suggests that application of Si may be used to enhance temperature tolerance of ferns.

\section{Literature Cited}

Agarie S, N. Hanaoka, O. Ueno, A. Miyazaki, F. Kubota, W. Agata, and P.B. Kaufman. 1998. Effect of silicon on tolerance to water deficit and heat stress in rice plants (Oryza sativa L.), monitored by electrolyte leakage. Plant Prod. Sci. 1:96-103.

Arnon, D.I. 1949. Copper enzyme in isolated chloroplasts: Polyphenol oxidase in Beta vulgaris. Plant Physiol. 24:1-15.

Bae, M.J., Y.G. Park, and B.R. Jeong. 2010. Effect of silicate fertilizer supplemented to a medium on the growth and development of potted plants. Flower Res. J. 18:50-56.

Brecht, M., C. Stiles, and L. Datnoff. 2009. Effect of high temperature stress and silicon fertilization on pathogenicity of Bipolaris cynodontis and Curvularia lunata on Floradwarf bermudagrass. Int. Turfgrass Soc. Res. J. 11:165-180.

Chen, W., X. Yao, K. Cai, and J. Chen. 2011. Silicon alleviates drought stress of rice plants by improving plant water status, photosynthesis and mineral nutrient absorption. Biol. Trace Elem. Res. 142:67-76.

Chen, W.R., J.S. Zheng, Y.Q. Li, and W.D. Guo. 2012. Effects of high temperature on photosynthesis, chlorophyll fluorescence, chloroplast ultrastructure, and antioxidant activities in fingered citron. Russ. J. Plant Physiol. 59:732-740.

Dawson, I.A., R.W. King, and R. van der Staay. 1991. Optimising conditions for growth of Nephrolepis ferns. Sci. Hort. 45:303-314.

Drees, L.R., L.P. Wilding, N.E. Smeck, and A.L. Senkayi. 1989. Silica in soils: Quartz and disordered silica polymorphs, p. 913-974. In: J.P. Dixon and S.B. Weed (eds.). Minerals in soil environment. 2nd ed. Soil Sci. Soc. Am. Book Ser. Madison, WI.

Ehret, D.L., J.G. Menzies, and T. Helmer. 2005. Production and quality of greenhouse roses in recirculating nutrient systems. Sci. Hort. 106:103-113.

Elliott, C.L. and G.H. Snyder. 1991. Autoclave-induced digestion for the colorimetric determination of silicon in rice straw. J. Agric. Food Chem. 39:1118-1119.

Epstein, E. 1994. The anomaly of silicon in plant biology. Proc. Natl. Acad. Sci. USA. 91:11-17.

Epstein, E. 1999. Silicon. Ann. Rev. Plant Physiol. Plant Mol. Biol. 50:641-664.

Erwin, J.E., R.D. Heins, and J.E. Faust. 1993. Thermomorphogenic and photoperiodic responses of Nephrolepis exaltata 'Dallas Jewel'. HortScience 28:182-184.

Gao, X., C. Zou, L. Wang, and F. Zhang. 2006. Silicon decreases transpiration rate and conductance from stomata of maize plants. J. Plant Nutr. 29:1637-1647.

Guo, W., Y.L. Hou, S.G. Wang, and Y.G. Zhu. 2005. Effect of silicate on the growth and arsenate uptake by rice (Oryza sativa L.) seedlings in solution culture. Plant Soil 272:173-181.

Guo, Y.P., H.F. Zhou, and L.C. Zhang. 2006. Photosynthetic 
characteristics and protective mechanisms against photooxidation during high temperature stress in two Citrus Species. Sci. Hort. 108:260-267.

Hodson, M.J., P.J. White, A. Mead, and M.R. Broadley. 2005. Phylogenetic variation in the silicon composition of plants. Ann. Bot. 96:1027-1046.

Hoshizaki, B.J. and R. Moran. 2001. Fern grower's manual. 2nd ed. Timber Press, Portland, Oregon, USA.

Hwang, S.J., H.M. Park, and B.R. Jeong. 2005. Effects of potassium silicate on the growth of miniature rose 'Pinocchio' grown on rockwool and its cut flower quality. J. Japan. Soc. Hort. Sci. 74:242-247.

Jeong, K.J., Y.S. Chon, S.H. Ha, H.K. Kang, and J.G. Yun. 2012. Silicon application on standard chrysanthemum alleviates damages induced by disease and aphid insect. Kor. J. Hort. Sci. Technol. 30:21-26.

Jiang, H. and G.S. Howell. 2002. Applying chlorophyll fluorescence technique to cold hardiness studies of grapevines. Am. J. Enol. Viticult. 53:210-217.

Kalaji, H.M., K. Bosa, J. Koscielniak, and Z. Hossain. 2011. Chlorophyll a fluorescence - A useful tool for the early detection of temperature stress in spring barley (Hordeum vulgare L.). OMICS J. Integr. Biol. 15:925-934.

Kamenidou, S., T.J. Cavins, and S. Marek. 2009. Evaluation of silicon as a nutritional supplement for greenhouse zinnia production. Sci. Hort. 119:297-301.

Kamenidou, S., T.J. Cavins, and S. Marek. 2008. Silicon supplements affect horticultural traits of greenhouse-produced ornamental sunflowers. HortScience 43:236-239.

Kamenidou, S., T.J. Cavins, and S. Marek. 2010. Silicon supplements affect floricultural quality traits and elemental nutrient concentrations of greenhouse produced gerbera. Sci. Hort. 123:390-394.

Kim, S.G., K.W. Kim, E.W. Park, and D. Choi. 2002. Siliconinduced cell wall fortification of rice leaves: A possible cellular mechanism of enhanced host resistance to blast. Phytopathology 92:1095-1103.

Liang, Y., Q. Shen, Z. Shen, and T. Ma. 1996. Effects of silicon on salinity tolerance of two barley cultivars. J. Plant Nutr. 19:173-183.

Liang, Y., W. Sun, Y.G. Zhu, and P. Christie. 2007. Mechanisms of silicon-mediated alleviation of abiotic stresses in higher plants: A review. Environ. Pollut. 147:422-428.

Ma, J.F. 2004. Role of silicon in enhancing the resistance of plants to biotic and abiotic stress. Soil Sci. Plant Nutr. 50:11-18.

Ma, J.F. and E. Takahashi. 1990. Effect of silicon on the growth and phosphorus uptake of rice. Plant Soil 126:115-119.

Ma, J.F. and E. Takahashi. 1993. Interaction between calcium and silicon in water-cultured rice plants. Plant Soil 148:107-113.

Ma, J.F. and N. Yamaji. 2006. Silicon uptake and accumulation in higher plants. Trends Plant Sci. 11:392-397.

Mateos-Naranjo, E., L. Andrades-Moreno, and A.J. Davy. 2013. Silicon alleviates deleterious effects of high salinity on the halophytic grass Spartina densiflora. Plant Physiol. Biochem. 63:115-121.

Mattson, N.S. and W.R. Leatherwood. 2010. Potassium silicate drenches increased leaf silicon content and affect morphological traits of several floricultural crops grown in a peat-based substrate. Hortscience 45:43-47.

Maxwell, K. and N.G. Johnson. 2000. Chlorophyll fluorescence - A practical guide. J. Exp. Bot. 51:659-668.

Moon, H.H., M.J. Bae, and B.R. Jeong. 2008. Effect of silicate supplemented medium on rooting of cutting and growth of chrysanthemum. Flower Res. J. 16:107-111.

Piperno, D.R. 1988. Phytolith analysis: An archaeological and geological perspective. Academic Press, San Diego.

Ranganathan, S., V. Suvarchala, Y.B.R.D. Rajesh, M. Srinivasa Prasad, A.P. Padmakumari, and S.R. Voleti. 2006. Effects of silicon sources on its deposition, chlorophyll content, and pest resistance in rice. Biol. Plant. 50:713-716.

Rodrigues, F.A., F.X.R. Vale, G.H. Komdorfer, A.S. Prabhu, L.E. Datnoff, A.M.A. Oliveira, and L. Zambolim. 2003. Influence of silicon on sheath blight of rice in Brazil. Crop Prot. 22: 23-29.

Roy, A.C., M.Y. Ali, R.L. Fox, and J.A. Silva. 1971. Influence of calcium silicate on phosphate solubility and availability in Hawaiian Latosols. Proc. Int. Symp. Soil Fert. Eval. New Delhi 1:757-765.

Salvucci, M.E. and S.J. Crafts-Brandner. 2004. Relationship between the heat tolerance of photosynthesis and the thermal stability of Rubisco activase in plants from contrasting thermal environments. Plant Physiol. 134:1460-1470.

Savvas, D., G. Manos, A. Kotsiras, and S. Souvaliotis. 2002. Effects of silicon and nutrient-induced salinity on yield, flower quality and nutrient uptake of gerbera grown in a closed hydroponic system. J. Appl. Bot. 76:153-158.

Shi, G., Q. Cai, C. Liu, and L. Wu. 2010. Silicon alleviates cadmium toxicity in peanut plants in relation to cadmium distribution and stimulation of antioxidative enzymes. Plant Growth Regul. 61:45-52.

Sivanesan, I., M.S. Son, J.Y. Song, and B.R. Jeong. 2013. Subirrigational supply of silicon affects the growth of three chrysanthemum cultivars. Hort. Environ. Biotechnol. 54:14-19.

Sivanesan, I., M.S. Son, C.S. Lim, and B.R. Jeong. 2011. Effect of soaking of seeds in potassium silicate and uniconazole on germination and seedling growth of tomato cultivars, Seogeon and Seokwang. Afr. J. Biotechnol. 10:6743-6749.

Sivanesan, I., M.S. Son, J.P. Lee, and B.R. Jeong. 2010. Effects of silicon on growth of Tagetes patula L. 'Boy Orange' and 'Yellow Boy' seedlings cultured in an environment controlled chamber. Propag. Ornam. Plants 10:136-140.

Voogt, W. and C. Sonneveld. 2001. Silicon in horticultural crops grown in soilless culture, p. 115-131. In: L.E. Datnoff, G.H. Snyder, and G.H. Korndorfer (eds.). Silicon in agriculture. Elsevier, Amsterdam. 
Wahid, A., S. Gelani, M. Ashraf, and M.R. Foolad. 2007. Heat tolerance in plants: An overview. Environ. Exp. Bot. 61:199-223.

Wang, X.S. and J.G. Han. 2007. Effects of $\mathrm{NaCl}$ and silicon on ion distribution in the roots, shoots and leaves of two alfalfa cultivars with different salt tolerance. Soil Sci. Plant Nutr. 53:278-285.

Wiese, H., M. Nikolic, and V. Römheld. 2007. Silicon in plant nutrition, p. 33-47. In: B. Sattelmacher and W.J. Horst (eds.). The apoplast of higher plants: Compartment of storage, transport and reactions. Springer, The Netherlands.

Zuccarini, P. 2008. Effects of silicon on photosynthesis, water relations and nutrient uptake of Phaseolus vulgaris under $\mathrm{NaCl}$ stress. Biol. Plant. 52:157-160. 